\title{
Effect of Two Virus Inactivation Methods: Electron Beam Irradiation and Binary Ethylenimine Treatment on Determination of Reproductive Hormones in Equine Plasma
}

\author{
By N. Chr. Kyvsgaard ${ }^{1}$, R. Høier ${ }^{2}$, I. Brück ${ }^{2}$ and P. Nansen ${ }^{1}$ \\ ${ }^{1}$ Danish Centre for Experimental Parasitology, and ${ }^{2}$ Section of Reproduction, Department of Clinical Studies, \\ The Royal Veterinary and Agricultural University, Frederiksberg, Denmark.
}

\begin{abstract}
Kyvsgaard, N. Chr., R. Høier, I. Brück and P. Nansen: Effect of two virus inactivation methods: Electron beam irradiation and binary ethylenimine treatment on determination of reproductive hormones in equine plasma. Acta vet. scand. 1997, 38, 225-233. - Ionizing irradiation and binary ethylenimine treatment have previously been shown to be effective for in-vitro inactivation of virus in biological material. In the present study the 2 methods were tested for possible effects on measurable concentrations of reproductive hormones in equine plasma (luteinizing hormone $(\mathrm{LH})$, folliclestimulating hormone $(\mathrm{FSH})$, progesterone $\left(\mathrm{P}_{4}\right)$, and oestradiol-17 $\left.\beta\left(\mathrm{E}_{2}\right)\right)$. The inactivation methods were electron beam irradiation with a dose from 11 to $44 \mathrm{kGy}$ or treatment with binary ethylenimine (BEI) in concentrations of 1 and $5 \mathrm{mmol} / \mathrm{L}$. Generally, there was a close correlation $(r>0.8, p<0.001)$ between pre- and post-treatment hormone levels. Thus, the different phases of the oestrous cycle could be distinguished on the basis of measured hormone concentrations of treated samples. However, both treatments significantly changed hormone concentrations of the plasma samples. For $\mathrm{LH}, \mathrm{FSH}$, and $\mathrm{E}_{2}$ the effect of irradiation and BEI treatment was depressive and dose-dependant. For $\mathrm{P}_{4}$ the effect of irradiation was also depressive and dose-dependant. However, the highest dose of BEI resulted in an increase of measured $\mathrm{P}_{4}$ concentration, which may be attributed to changes in the plasma matrix due to the treatment. Although the treatments affected measured hormone concentrations, the close correlation between pre-treatment and post-treatment measurements means that the diagnostic value will remain unchanged.
\end{abstract}

luteinizing; follicle; progesterone; oestradiol.

\section{Introduction}

International research collaboration often requires the possibility for exchanging biological material e.g. for validation of test systems. If this material contains infective agents such as Foot and Mouth Disease Virus, African Horsesickness Virus, or Equine Encephalitis Virus this might constitute a risk to the recipient country. It is therefore imperative to find meth- ods which can safely inactivate virus in serum and plasma samples. As reproductive problems limit the success of tropical livestock, hormone analysis can be useful in improving breeding efficiency. Many developing countries lack, however, often equipment, reagents and/or expertise for these techniques, for which reason the material has to be shipped to other laboratories either regionally or overseas. 
Methods to inactivate viruses in biological material have previously been developed for inactivation of virus in vaccines or for diagnostic antigens. Two of the most widespread methods are ionizing irradiation and chemical treatment with binary ethylenimine (BEI).

The virucidal effect of ionizing irradiation is due to the formation of highly reactive free radicals causing loss of aromaticity of purine and pyrimidine rings as well as hydrolysis of the RNA or DNA backbone chain (Polatnick \& Bachrach 1968, Latarjet et al. 1972). Gamma irradiation has been tested against a range of viruses (Sullivan et al. 1971, Sun et al. 1978, Thomas et al. 1981, Elliot et al. 1982, Saliki et al. 1993). Electron beam irradiation has a lower penetration rate than $\gamma$-irradiation, but it has the advantage that the treatment lasts seconds rather than hours (Huber 1952).

BEI has proved to be efficient against a number of viruses (Bahnemann 1975, Bahnemann 1976, Sun et al. 1978, King 1991). BEI is prepared in solution from bromoethylamine (BEA) under alkaline conditions (Bahnemann 1975).

Compared to the abundance of literature on virus inactivation for vaccine preparation or for diagnostic antigens, less attention has been paid to the inactivation of virus in serum or plasma samples, which constitutes a different environment characterized by e.g. a high protein content (Bahnemann 1976, House et al. 1990, King 1991). Inactivation of virus in serum is expected to need higher doses of the inactivant compared to media with a lower protein content (Sullivan et al. 1971, Sullivan et al. 1973). In previous studies electron beam irradiation and chemical treatment with BEI have proved efficient for the inactivation of virus in bovine serum samples (Preuss et al. 1997), and their detrimental effect on antibodies in serum has been evaluated in bovine and porcine sera (Kyvsgaard et al. 1996). Both methods were found to have a satisfactory margin between vi- rus inactivation and damage to antibody activity, which allows reliable interpretation of results from treated samples.

The mentioned methods of inactivation have not previously been evaluated for their effect on hormones. The possibility exists that the effect of inactivation varies between peptide hormones and steroid hormones, and the present study was therefore designed to cover both groups, luteinizing hormone ( $\mathrm{LH})$ and folliclestimulating hormone (FSH) representing the peptide hormones and progesterone $\left(\mathrm{P}_{4}\right)$ and oestradiol-17 $\beta\left(\mathrm{E}_{2}\right)$ representing steroid hormones. The irradiation and BEI doses were chosen according to those considered necessary in other studies to inactivate some of the more resistant viruses in serum (Bahnemann 1976, House et al. 1990, Preuss et al. 1997). The dose range of irradiation was also in accordance with requirements from authorities in the European Union (EU), where irradiation with $25 \mathrm{kGy}$ is mentioned as one of the methods to achieve virological safety of bovine and porcine serum (Anon. 1992).

\section{Materials and Methods \\ Sample material}

Blood samples were taken daily from the jugular vein into heparinized vials (Vacutainers ${ }^{\circledR}$, Becton-Dickinson, USA) from a Norwegian Fjord mare during a complete oestrous cycle (22 days) in which the cyclic changes of the reproductive tract (folliculogenesis, ovulation, etc.) were monitored by echographic surveillance. The mare ovulated on day 22 of the oestrous cycle. Plasma was isolated by centrifugation, $3,000 \mathrm{~g}$ for $10 \mathrm{~min}$ and stored at $-20^{\circ} \mathrm{C}$ in aliquots of $1 \mathrm{~mL}$ until inactivating treatment.

\section{Irradiation}

Part of the aliquots was subjected to irradiation from a $10 \mathrm{MeV}$ electron accelerator at Risø $\mathrm{Na}$ tional Laboratory (Denmark). The tubes were 
irradiated from above with $0,11,22,33$ or 44 kGy. To keep the samples in frozen state they were irradiated on an ice/salt mixture. In order to compensate for the low penetrative ability of the electron beam irradiation, the tubes containing plasma samples were positioned horizontally in one layer on the ice/salt and covered with a 1-cm layer of ice/salt. After irradiation the samples were stored at $-20^{\circ} \mathrm{C}$ until analysis.

\section{Binary etylenimine (BEI) treatment}

BEI in aqueous solution $(0.1 \mathrm{~mol} / \mathrm{L})$ was freshly prepared as described by Bahnemann (1975): Briefly, 4\% of 2-bromoethylamine hydrobromide (BEA) was incubated with an equal volume of $0.4 \mathrm{~N} \mathrm{NaOH}$; the reaction was allowed to take place at $37^{\circ} \mathrm{C}$ for $1 \mathrm{~h}$ under agitation. This BEI-solution was then added to 2 aliquots to give final concentrations of 1 $\mathrm{mmol} / \mathrm{L}$ and $5 \mathrm{mmol} / \mathrm{L}$, respectively. (When corrected for dilution by the added volume of the BEI solution the concentrations were 0.99 and $4.76 \mathrm{mmol} / \mathrm{L}$, respectively). The inactivation took place at $37^{\circ} \mathrm{C}$ for $24 \mathrm{~h}$. After BEI treatment the samples were stored at $-20^{\circ} \mathrm{C}$ until used.

\section{Hormone analyses}

Luteinizing hormone ( $\mathrm{LH})$ was determined by employing a previously described competitive radioimmunoassay (RIA) method (Worthy et al. 1987) as evaluated in our laboratory (Høier 1994).

FSH was determined with the assistance of a commercial fluoroimmunoassay FSH kit, Del$\mathrm{fia}^{\circledR} \mathrm{hFSH}$ which was constructed for the determination of human FSH. Data on cross-reactivity (CR) from equine gonadotropins were unavailable. Recognition of equine FSH was initially investigated by analysis of different concentrations of an equine FSH reference preparation (E265B) according to the protocol supplied with the kit. The analysis for equine
FSH was designed by using equine FSH for calibration: E265B was diluted to standard concentrations covering 0 to $80 \mu \mathrm{g} / \mathrm{L}$ with standard diluent, a 1:1 mixture of Delfia ${ }^{\circledR}$ assay buffer and bovine plasma, which did not give any response in the assay. The protocol suggested by the manufacturer was modified slightly in order to improve sensitivity. Binding of FSH in $50 \mu \mathrm{L}$ volumes of standards and samples to the anti$\mathrm{FSH} \beta$-antibody coated microtiter wells and to the tracer was performed as a two-step reaction, 180 and $45 \mathrm{~min}$, respectively, and the wells were subjected to additional washing prior to addition of enhancer. CR from equine $\mathrm{LH}$ (E263B) and chorionic gonadotropin (Crude PMSG, UCB-bioproducts) were studied by analyzing known amounts in standard diluent. The analytical precision expressed as the intraand inter-assay coefficients of variation (CV\%), sensitivity and accurary expressed as the recovery of added known amounts of the hormone was performed as described by Jensen et al. (1993).

$\mathrm{P}_{4}$ was measured using a competitive enzymelinked immunosorbent assay (ELISA) as previously described by Høier (1989) with the exceptions that equine progesterone-free plasma was used for construction of standards, and the analysis was performed as a $3-\mathrm{h}$ incubation at room temperature. These modifications did not affect characteristics of the analysis. The main cross-reacting steroid was $11 \alpha$-hydroxyprogesterone $5 \%$, and other steroids tested crossreacted below $0.2 \%$; intra- and inter-assay coefficients of variation were $3 \%-10 \%$ and $7 \%$ $15 \%$, respectively, depending on position on the standard curve.

$\mathrm{E}_{2}$ was quantified by use of a double antibody RIA kit designed to measure $\mathrm{E}_{2}$ in human serum or plasma (Diagnostic Products Corporation, Los Angeles, California, USA). The anti- $E_{2}$ antibody was reported to carry the following CR's: $\mathrm{E}_{2} 100 \%$, oestrone $12.5 \%, 17 \beta$ - 
oestradiol-3 $\beta$-D-glucuronide $6.0 \%$, d-equilenin $4.2 \%$, other steroids tested $<3.5 \%$. The protocol suggested by the manufacturer was followed with some modifications: In order to approach matrix identity between standards and samples, the kit's standards were diluted 1:1 with plasma from a gelding, and the mare samples were diluted 1:1 with the kits 0 -calibrator. Diluted standards and samples were added anti- $\mathrm{E}_{2}$-antiserum and incubated for $3 \mathrm{~h}$ at $4^{\circ} \mathrm{C}$. Following addition of tracer, the incubation was continued overnight at $4{ }^{\circ} \mathrm{C}$. Intra- and inter-assay coefficients of variations (CV\%) were $4.8 \%$ and $7.1 \%$, respectively, in the range from 92 to 367 $\mathrm{pmol} / \mathrm{L}$, thus being comparable to the analytical variation stated by the manufacturer, intra-assay CV\% 4\%-8\% and inter-assay CV\% 3.5\%$5.5 \%$. Analysis of samples made by addition of different, known concentrations of $\mathrm{E}_{2}$ confirmed a straight-line recovery not different from $100 \%$ in the range from $0-184 \mathrm{pmol} / \mathrm{L}$ of added $\mathrm{E}_{2}$.

\section{Statistical methods}

Routine statistical procedures like determination of mean, standard deviation (SD), and coefficient of variation (CV\%), computation of pooled-variance estimates, lack-of-fit testing (LOF), T-statistics, and processing of linear regression models were according to standard procedures (Box et al. 1978). Sensitivity was calculated as the least detectable concentration (LDC), which could not be distinguished from zero value at a probability of $5 \%$. The slope $\left(\beta_{1}\right)$ for each comparison between control and treatment groups was tested for the hypothesis $\beta_{1}=$ 1 , i.e. that the measured posttreatment concentration was equal to pretreatment activity.

\section{Results}

Effect of irradiation on hormone analyses

Plasma samples from a mare throughout a com- plete oestrous cycle were subjected to increasing doses of electron beam irradiation, and ensuing this, the contents of $\mathrm{LH}, \mathrm{FSH}, \mathrm{P}_{4}$ and $\mathrm{E}_{2}$ were measured. The resulting hormone concentrations were correlated to the concentrations prior to treatment by linear regressions (Fig. 1), the results of which are summarized in Table 1. It can be seen that for all 4 hormones the degree of irradiation was reflected in the measured hormone concentrations so that increasing doses were accompanied by a decrease in hormone concentrations. The regression lines all fitted straight-line models. The intercept with the $y$-axis $\left(\beta_{\mathrm{o}}\right.$ in Table 1$)$ was only significantly different from 0 in 2 of the 16 combinations of irradiation dose and hormone. Investigations of regression models revealed no familiarity between the different peptide or steroid hormones (data not shown). For the purpose of comparing pre- and post-treatment profiles Fig. 2 shows hormone immunoactivity during the complete oestrous cycle determined on untreated and maximally irradiated samples, respectively.

\section{Effect of ethylenimine treatment on hormone analyses}

Plasma samples from a cycling mare were subjected to 2 doses of BEI, and ensuing this, the content of $\mathrm{LH}, \mathrm{FSH}, \mathrm{P}_{4}$, and $\mathrm{E}_{2}$ were measured. The result of comparing measured hormone concentrations with the concentrations found prior to treatment with ethylenimine is outlined as regression analyses in Table 1. It can be seen that $1 \mathrm{mmol} / \mathrm{L}$ of BEI did not affect hormone measurements. Five $\mathrm{mmol} / \mathrm{L}$, in contrast, resulted in a significant decrease in $\mathrm{E}_{2}$ and $\mathrm{FSH}$ concentrations, LH concentrations remained unchanged, and $\mathrm{P}_{4}$ concentrations increased significantly. Fig. 2 shows hormone immunoactivity during the complete oestrous cycle determined on untreated and BEI treated samples, respectively. 

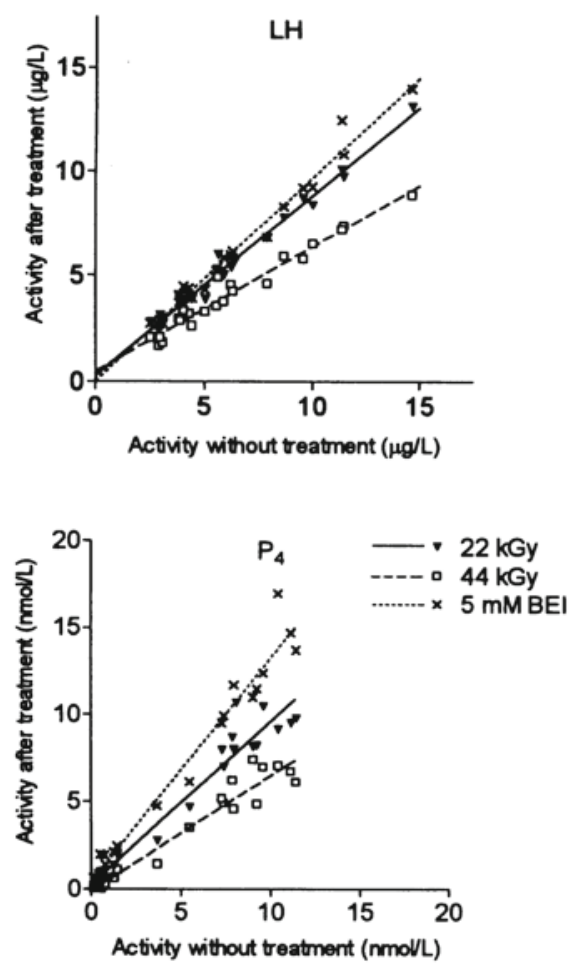
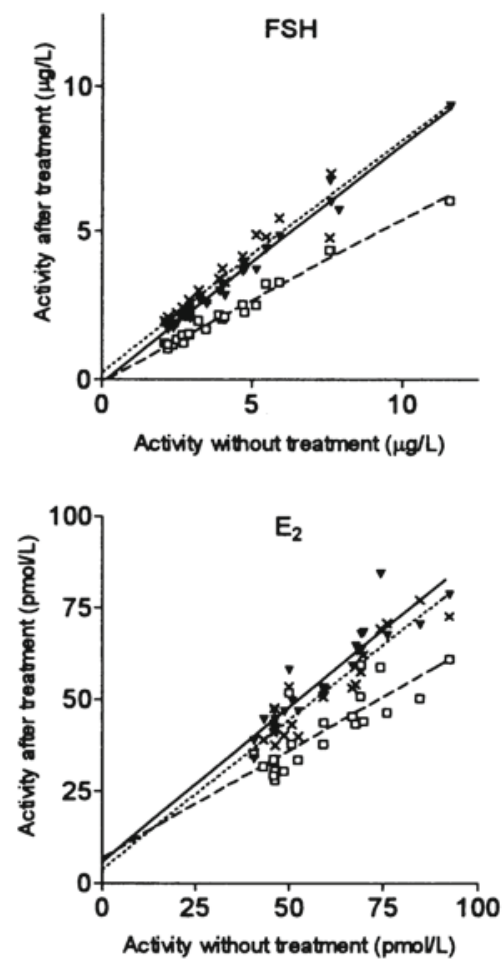

Figure 1. Measured plasma concentrations of reproductive hormones plotted against the activity of untreated samples. Values and regression lines are shown for $22 \mathrm{kGy}$ and $44 \mathrm{kGy}$ irradiation as well as for treatment with $5 \mathrm{mmol} / \mathrm{L}$ BEI.

\section{Validation of the FSH analysis}

Initial investigations showed that equine FSH responded significantly in the Delfia ${ }^{\circledR} \mathrm{hFSH}$ kit. The result is summarized in the regression equation $(\mathrm{X}, \mathrm{Y})=($ Added equine $\mathrm{FSH}$, measured human $\mathrm{FSH} ; \mu \mathrm{g} / \mathrm{L}): \mathrm{Y}=-1.048+$ $0.145 \cdot \mathrm{X}, \mathrm{n}=16, \mathrm{r}=0.989, \mathrm{p}<0.0001$. Equine LH and CG responded slightly, but CR's were less than $1 \%$ as compared to equine FSH. Intraassay CV\% for low and high FSH concentrations was calculated to be $7.1 \%(\mathrm{n}=90$, mean $=$ $2.12 \mu \mathrm{g} / \mathrm{L}, \mathrm{SD}=0.15 \mu \mathrm{g} / \mathrm{L})$ and $3.7 \%(\mathrm{n}=101$, mean $=6.53 \mu \mathrm{g} / \mathrm{L}, \mathrm{SD}=0.24 \mu \mathrm{g} / \mathrm{L})$, respectively, according to pooled-variance estimates. Inter-assay $\mathrm{CV} \%$ was $10.6 \%$ when calculated as the assay-to-assay variation of different sam- ples $(\mathrm{n}=15$, mean $=3.65 \mu \mathrm{g} / \mathrm{L}, \mathrm{SD}=0.39$ $\mu \mathrm{g} / \mathrm{L}) . \mathrm{LDC}$ was $0.19 \mu \mathrm{g} / \mathrm{L}(\mathrm{SD}=0.093 \mu \mathrm{g} / \mathrm{L})$. The recovery of $10 \mu \mathrm{g} / \mathrm{L}$ equine $\mathrm{FSH}$ (E265B) added to various samples was $100 \%(n=15$, recovered $=9.81 \mathrm{~g} / \mathrm{L}, \mathrm{p}=0.23$ in a paired T-test).

\section{Discussion}

Effects of irradiation and BEI treatment on hormone analyses

Both irradiation and ethylenimine treatment of mare plasma samples influenced on the result of hormone analyses. Irradiation resulted in a dose dependent response where increased dose was reflected in a lower slope in regression analysis of post-treatment vs. pre-treatment 
Table 1. Correlation between measured concentrations of luteinizing hormone (LH), follicle stimulating hormone (FSH), progesterone $\left(\mathrm{P}_{4}\right)$, and oestradiol-17 $\beta\left(\mathrm{E}_{2}\right)$ in mare plasma samples exposed to 4 different doses of electron beam irradiation or 2 doses of binary ethylenimine (BEI) versus non-treated samples.

\begin{tabular}{|c|c|c|c|c|c|c|}
\hline $\begin{array}{l}\text { Dose } \\
\mathrm{N}\end{array}$ & $\begin{array}{c}11 \\
\text { kGy } \\
23\end{array}$ & $\begin{array}{c}22 \\
\mathrm{kGy} \\
23\end{array}$ & $\begin{array}{c}33 \\
\text { kGy } \\
22\end{array}$ & $\begin{array}{c}44 \\
\text { kGy } \\
22\end{array}$ & $\begin{array}{c}1 \\
\mathrm{mmol} / \mathrm{L} \\
13\end{array}$ & $\begin{array}{c}5 \\
\mathrm{mmol} / \mathrm{L} \\
21\end{array}$ \\
\hline \multicolumn{7}{|l|}{$L H:$} \\
\hline$r$ & 0.994 & 0.992 & 0.986 & 0.981 & 0.956 & 0.990 \\
\hline$\beta_{0}$ & ${ }^{\mathrm{ns}} 0.128$ & ns 0.292 & $* 0.472$ & $* 0.495$ & ns_- 0.060 & ${ }^{\mathrm{ns}} 0.032$ \\
\hline$\beta_{1}$ & $* 0.947$ & $* * * 0.852$ & $* * * 0.743$ & $* * * 0.587$ & $\mathrm{~ns} 1.00$ & ns 0.963 \\
\hline \multicolumn{7}{|l|}{ FSH: } \\
\hline $\mathrm{r}$ & 0.993 & 0.991 & 0.986 & 0.991 & 0.985 & 0.947 \\
\hline$\beta_{0}$ & ns -0.057 & ns_- 0.090 & ns -0.063 & ns -0.070 & ${ }^{\mathrm{ns}} 0.297$ & ${ }^{\mathrm{ns}} 0.263$ \\
\hline$\beta_{1}$ & ${ }^{* *} 0.889$ & $* * * 0.808$ & $* * * 0.724$ & $* * * 0.550$ & $\mathrm{~ns} 1.025$ & $* * 0.791$ \\
\hline \multicolumn{7}{|l|}{$P_{4}:$} \\
\hline$r^{4}$ & 0.976 & 0.974 & 0.977 & 0.973 & 0.998 & 0.985 \\
\hline$\beta_{0}$ & ${ }^{\mathrm{ns}} 0.202$ & ${ }^{\mathrm{ns}} 0.287$ & ${ }^{\mathrm{ns}} 0.152$ & ns_- 0.092 & ${ }^{\mathrm{ns}} 0.285$ & ${ }^{\text {ns }} 0.429$ \\
\hline$\beta_{1}$ & ${ }^{\mathrm{ns}} 1.085$ & ${ }^{\mathrm{n} s} 0.934$ & $* * * 0.833$ & $* * * 0.660$ & ${ }^{\mathrm{n} s} 1.024$ & $* * * 1.283$ \\
\hline \multicolumn{7}{|l|}{$E_{2}:$} \\
\hline $\mathrm{r}^{2}$ & 0.953 & 0.925 & 0.902 & 0.826 & 0.940 & 0.940 \\
\hline$\beta_{0}$ & ns 5.70 & ns5.91 & ns5.89 & ns 6.93 & ${ }^{\mathrm{ns}} 0.607$ & ns 3.82 \\
\hline$\beta_{1}$ & ${ }^{\text {ns }} 0.910$ & $* 0.842$ & $* 0.774$ & $* * 0.584$ & ${ }^{\mathrm{ns}} 0.994$ & ${ }^{*} 0.813$ \\
\hline
\end{tabular}

$\mathrm{N}=$ number of observations. $\beta_{0}$ and $\beta_{1}=$ intercept and slope of regression; $\mathrm{r}=$ coefficient of correlation. $\mathrm{ns},{ }^{*}$, ${ }^{* *},{ }^{* * *}=$ statistical significance for slope $\neq 1$, corresponding to nonsignificant, $\mathrm{p}<0.05, \mathrm{p}<0.01, \mathrm{p}<0.001$, respectively.

measured activity. The slopes of the regression lines for the highest dose ( $44 \mathrm{kGy})$ were $\beta_{1}=$ $0.59,0.55,0.66,0.58$ for $\mathrm{LH}, \mathrm{FSH}, \mathrm{P}_{4}$ and $\mathrm{E}_{2}$, respectively. When comparing the slopes of the posttreatment vs. pretreatment regression lines (Table 1) dose-effect correlations were found which were independent of both molecular size and type of hormone, steroid hormone versus peptide hormone since each hormone had its own dose-decay curve. Treatment of plasma samples with BEI resulted in decreasing hormone concentrations, with the exception that $\mathrm{P}_{4}$ concentrations were elevated.

Generally, changes in measured hormone concentrations after treatment can be caused by two main mechanisms: Firstly, the treatment(s) could change the hormone molecules such that it is not recognized by the antibody (-ies). Concerning irradiation this effect can be either through direct hit by the incoming electron or, which is more likely for small molecules, through reactions with free radicals formed by the irradiation (Thomas et al. 1981). Secondly, a general detriment of proteins and other plasma components might well affect the binding between antibody and hormone, i. e. change the antibody affinity. Thus, the apparently higher $\mathrm{P}_{4}$ concentration could be caused by either a changed binding between carrier proteins and $\mathrm{P}_{4}$ or it might be due to changes in the plasma matrix which could influence the immunoassay. In this study it is difficult to judge which effect is the most dominating in the various hormone assays. 

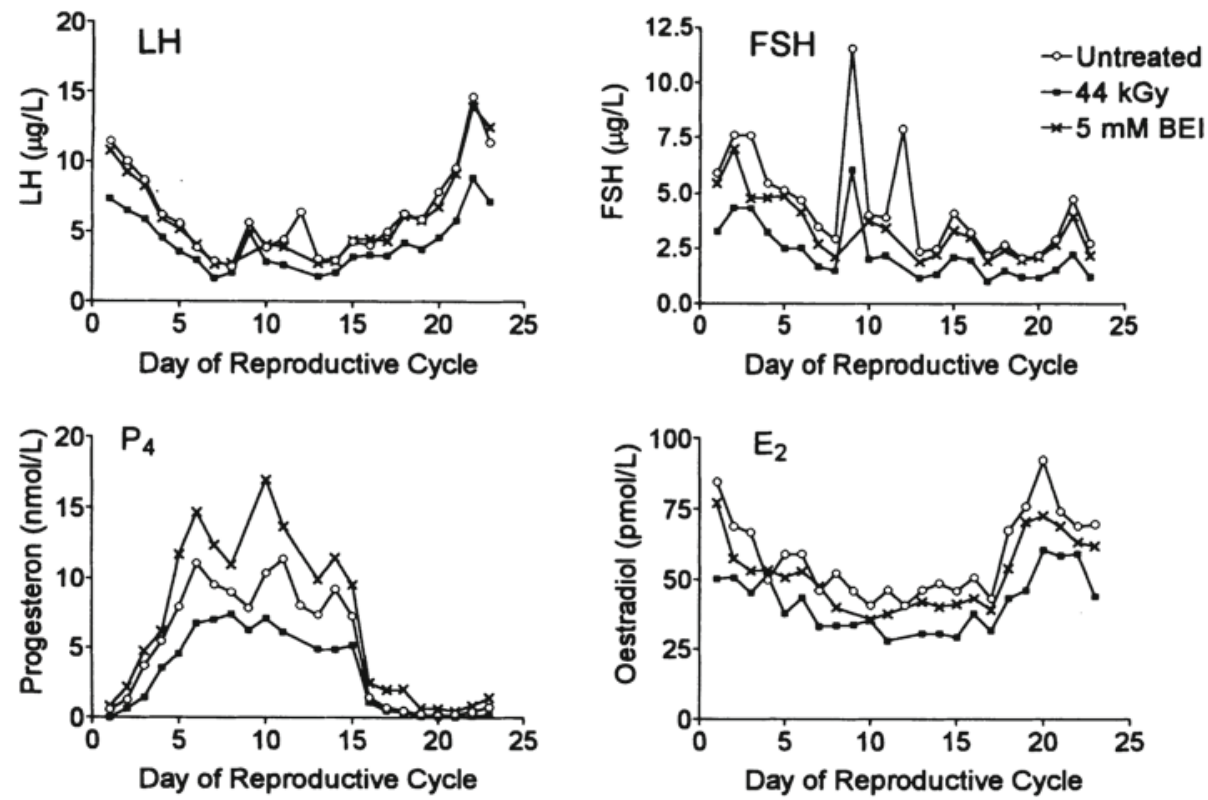

Figure 2. Measured plasma concentrations of reproductive hormones during an oestrous cycle for untreated samples, samples irradiated with $44 \mathrm{kGy}$ and samples treated with $5 \mathrm{mmol} / \mathrm{L}$ BEI for $24 \mathrm{~h}$. Values are missing for the $44 \mathrm{kGy}$ irradiated samples at day 12 and for the BEI treated samples at day 9 and day 12 .

\section{Validation of hormone analyses}

In this study it was shown possible to determine equine FSH in plasma samples with a commercially available fluoroimmunoassay (Delfia ${ }^{\circledR}$ ) designed for the measurement of human FSH. This finding was not unexpected since heterologous assays have previously proven valid for the evaluation of follicle-stimulating activity in mares (Alexander et al. 1987, Hines et al. 1991, Høier 1994), thereby stating a high degree of interspecies homology. It can be concluded that the Delfia ${ }^{\circledR} \mathrm{hFSH}$ kit is suitable for monitoring of the cyclic fluctuation in mares, especially since the low CR from LH and CG will not confound the FSH results. It cannot be excluded that at least part of the measured CR's are caused by amounts of FSH in the hormone preparations. Assay precision and accuracy appeared acceptable, and the least detectable con- centration in the assay was well below the lowest FSH concentrations measured.

Applications of virus-inactivated plasma hormone concentrations

EU regulations for biological materials mention irradiation with $25 \mathrm{kGy}$ as one possible method for virus-inactivation in sera (Anon. 1992). It has been concluded above that irradiation of mare plasma samples with this or higher doses or exposure to BEI affects the outcome of subsequent hormone analyses. This fact will, however, not necessarily declare virus-inactivated material to be un-useful for hormone measurements, since the concentrations of $\mathrm{LH}, \mathrm{FSH}, \mathrm{P}_{4}$, and $\mathrm{E}_{2}$ in the treated material are proportional and highly correlated to the concentrations prior to virus-inactivation. Hormone profiles of treated samples will thereby be parallel to pro- 
files of untreated material (Fig. 2). The profiles will not reflect the actual hormone concentrations, but still the diagnostic value of hormone measurements will remain unchanged.

\section{Acknowledgements}

This study was financed by Danida, ENRECA Programme (Project No. 104.Dan.8.L/704). We wish to thank the staff at Risø National Laboratory, Accelerator Unit for their assistance in performing the irradiations. The free use of Delfia fluoroimmunoassay equipment together with the free supply of kit material for evaluation of the FSH analysis by Wallac (Turku, Finland) is gratefully appreciated as is the kind donation of purified equine FSH (E265B) and LH (E263B) by Dr. Harold Papkoff (University of California, USA). The skilled work by Ms. B. Synnestvedt and Ms. P. Rasmussen is also to be acknowledged.

\section{References}

Alexander SL, Irvine CHG, Turner JE: Comparison by three different radioimmunoassay systems of the polymorphism of plasma FSH in mares in various reproductive states. J. Reprod. Fert., 1987, Suppl. 35, 9-18.

Anonymous: Council Directive 92/118/EEC of 17 December 1992 laying down animal health and public health requirements governing trade in and imports into the Community of products not subject to the said requirements laid down in specific Community rules referred to in Annex A (I) to Directive 89/662/EEC and, as regards pathogens, to Directive 90/425/EEC.

Bahnemann HG: Binary Ethylenimine as an Inactivant for Foot-and-Mouth Disease Virus and Its Apllication for Vaccine Production. Arch. Virol. 1975, 47, 47-56.

Bahnemann $H G$ : Inactivation of Viruses in Serum with Binary Ethyleneimine. J. Clin. Microbiol. 1976, 3, 209-210.

Box GEP, Hunter WG, Hunter JS: Statistics for Experimenters, New York, U.S.A., John Wiley \& Sons, Inc., 1978, 653pp.

Elliot LH, McCormick JB, Johnson KM: Inactivation of Lassa Marburg, and Ebola Viruses by Gamma Irradiation. J. Clin. Microbiol. 1982, 16, 704-708.

Hines $K K$, Affleck $K J$, Barrows $S P$, Murdoch $W L$, Fitzgerald BP, Loy $R G$ : Follicle-Stimulating Hormone Pulse Amplitude with the Onset of the
Breeding Season in the Mare. Biol. Reprod. 1991, 44, 516-521.

House C, House JA, Yedloutschnig RJ: Inactivation of viral agents in bovine serum by gamma irradiation. Can. J. Microbiol. 1990, 36, 737-740.

Huber W: Cold Sterilization by Electron Beam as a Possible Tool for the Inactivation of the Virus of Homologous Serum Jaundice in Plasma. Ann. N. Y. Acad. Sci. 1952, 55, 536-542.

Høier R: Determination of Plasma Progesterone in the Blue Fox (Alopex lagopus) at Pro-oestrus and Oestrus by Use of a Commercial Kit. Acta Agric. Scand. 1989, 39, 181-186.

Høier R: Determination of Equine Follicle-stimulating Hormone Assisted by A Commercially Available Enzymeimmunoassay Kit. Reprod. Domestic Anim. 1994, 29, 289-295.

Jensen AL, Høier R, Poulsen JSD: Adaptation of a commercially available enzyme linked immunosorbent assay (ELISA) for the determination of thyroxine in canine plasma samples. J. Vet. Med. Ser. A 1993, 39, 741-746.

King DJ: Evaluation of Different Methods of Inactivation of Newcastle Disease Virus and Avian Influenza Virus in Egg Fluids and Serum. Avian Dis. 1991, 35, 505-514.

Kyvsgaard NC, Lind P, Preuss T, Kamstrup S, Lei JC, Bøgh HO, Nansen P: The activity of antibodies against Salmonella dublin, Toxoplasma gondii or Actinobacillus pleuropneumoniae in sera after treatment with electron beam irradiation or binary ethylenimine. Clin. Diag. Lab. Immunol. 1996, 3, 628-634.

Latarjet $R$ : Interaction of Radiation Energy with Nucleic Acids. Curr. Top. Radiat. Res. Q. 1972, 8, 138.

Polatnick J, Bachrach HL: Ionizing Irradiation of Foot-and-Mouth Disease Virus and Its Ribonucleic Acid. Arch. gesamte Virusforsch. 1968, 23, 96-104.

Preuss T, Kamstrup S, Kyvsgaard, NC, Lei JC, Nansen P, Miller A: Comparison of Two Different Methods for Inactivation of Viruses in Serum. Submitted for publication.

Saliki JT, Berninger ML, Torres A, House JA, Mebus $C A$, Dubovi EJ: Effect of Gamma Irradiation on Reactivity of Rinderpest Virus Antigen with Bovine Immune Serum in Enzyme-Linked Immunosorbent Assay and Virus Neutralization and Indirect Flourescent-Antibody Tests. J. Clin. Microbiol. 1993, 31, 428-432.

Sullivan R, Scarpino VS, Fassolitis AC, Larkin EP, 
Peeler JT: Gamma Radiation Inactivation of Coxsackievirus B-2. Appl. Microbiol. 1973, 26, 14-17.

Sullivan R, Fassolitis AC, Larkin EP, Read RB, Peeler $J T$ : Inactivation of Thirty Viruses by Gamma Radiation. Appl. Microbiol. 1971, 22, 61-65.

Sun IL, Gustafson DP, Scherba G: Comparison of Pseudorabies Virus Inactivated by Bromo-Ethylene-Imine, ${ }^{60}$ Co Irradiation, and Acridine Dye in Immune Assay Systems. J. Clin. Microbiol. 1978, $8,604-611$.

Thomas FC, Davies AG, Dulac GC, Willis NG, PappVid G, Girard A: Gamma Ray Inactivation of Some Animal Viruses. Can. J. comp. Med. 1981, 45, 397-399.

Worthy K, Colquhoun K, Escreet R, Dunlop M, Renton JP, Douglas TA: Plasma Prolactin Concentrations in Non-pregnant Mares at Different Times of the Year and in Relation to Events in the Cycle. J. Reprod. Fert. 1987, 35, 269-276.

\section{Sammendrag}

Effekt af to virus inaktiveringsmetoder (Elektronbestråling og binar etylenimin behandling) på bestemmelse af reproduktionshormoner i equin plasma.

Det er tidligere blevet påvist at bestråling og behand- ling med binær etylenimin er effektive metoder til inaktivering af virus $\mathrm{i}$ biologisk materiale. I nærværende arbejde blev de to metoder vurderet for deres mulige virkning på de målte koncentrationer af reproduktions hormoner i equin plasma (luteiniserende hormon $(\mathrm{LH})$, follikel-stimulerende hormon (FSH), progesteron $\left(\mathrm{P}_{4}\right)$, og østradiol-17 $\left.\beta\left(\mathrm{E}_{2}\right)\right)$. Inaktiveringsmetoderne var elektron-bestråling med doser fra 11 til $44 \mathrm{kGy}$ eller behandling med binær etylenimin (BEI) i koncentrationer på 1 og $5 \mathrm{mmol} / \mathrm{L}$. Generelt var der en tæt korrelation $(r>0,8, p<0,001)$ mellem præ- og post-behandlings hormon bestemmelser. Således kunne de forskellige faser af østral cyklus identificeres på basis af de målte koncentrationer i de behandlede prøver. Begge behandlinger ændrede ganske vist hormon koncentrationerne i plasma prøverne. De målte koncentrationer af $\mathrm{LH}$, FSH og $\mathrm{E}_{2}$ blev ændret i negativ retning i et omfang der var afhængig af dosis. Bestråling resulterede også $i$ en reduktion af de målte koncentrationer af $\mathrm{P}_{4}$, hvorimod den højeste dosis af BEI resulterede i en forøgelse af de målte $\mathrm{P}_{4}$ koncentrationer, hvilket kan skyldes forandringer i plasma matrix som følge af behandlingen. Selv om begge behandlingsformer ændrede de målte hormon koncentrationer var der en tæt korrelation mellem præ-behandlings og post-behandlings målinger hvorved den diagnostiske værdi ikke blev affekteret.

(Received January 24, 1997; accepted April 3, 1997).

Reprints may be obtained from: N. Chr. Kyvsgaard, Danish Centre for Experimental Parasitology, The Royal Veterinary and Agricultural University, Bülowsvej 13, DK-1870 Frederiksberg C, Denmark. E-mail: nck@kvl.dk, Fax: +45 3528 2774, tel: +45 35282785. 